\title{
PENINGKATAN BERPIKIR KRITIS MELALUI METODE PROBLEM BASED LEARNING SISWA KELAS IV SDN PINANG 6 TANGERANG
}

\author{
${ }^{1}$ Wiwi Ulandari, S.Pd, ${ }^{2}$ Ferry Perdiansyah, M.Pd, ${ }^{3}$ Moh. Zamroni, M.Pd \\ Program Studi Pendidikan Guru Sekolah Dasar \\ Universitas Muhammadiyah Tangerang \\ wiwiu21@gmail.com, ferry_perdiansyah@yahoo.co.id, zamroni0711@yahoo.com
}

\begin{abstract}
Abstrak
Penelitian ini bertujuan untuk mengetahui apakah terdapat peningkatan kemampuan berpikir kritis dengan pembelajaran IPA materi gaya. Penelitian ini menggunakan metode penelitian PTK . Sampel dalam penelitian ini adalah seluruh siswa kelas IV A SD Negeri Pinang 6 Kecamatan Pinang Kota Tangerang yang berjumlah 40 siswa . Teknik pengumpulan data dengan menggunakan instrument soal uraian dan observasi. Data yang terkumpul dianalisis untuk mengukur peningkatan indikator keberhasilan yang sudah dirumuskan. Pelaksanaan dilakukan dalam dua siklus. Pelaksanaan ini untuk mengukur peningkatan kemampuan berpikir kritis. Pada siklus I kemampuan berpikir kritis siswa rata-rata 67,5 dan pada siklus II kemampuan berpikir kritis siswa ratarata 92. Dari hasil penelitian ini bahwa pembelajaran IPA dengan menggunakan metode Problem Based Learning pada materi gaya berhasil diterapkan dan dapat meningkatkan kemampuan berpikir kritis siswa . Jadi dapat disimpulkan bahwa terjadi peningkatan hasil belajar siswa dari 57,5\% menjadi $95 \%$.
\end{abstract}

Kata Kunci : Berpikir Kritis, Metode Problem Based Learning, Pembelajaran IPA

\begin{abstract}
This study aims to determine whether there is an increase in the ability to think critically with learning science material style. This study uses the PTK research method. The sample in this study were all students of class IV A Pinang 6 Public Elementary School Pinang District Tangerang City, which amounted to 40 students. Data collection techniques using the instrument description and observation questions. The data collected is analyzed to measure the improvement in the indicators of success that have been formulated. The implementation is carried out in two cycles. This exercise is to measure the increase in critical thinking skills. In the first cycle the students 'critical thinking skills averaged 67.5 and in the second cycle the students' critical thinking abilities averaged 92. From the results of this study that science learning using the Problem Based Learning method on style material was successfully applied and could improve critical thinking skills the student. The conclusion is an increase in student learning outcomes from $57.5 \%$ to $95 \%$.
\end{abstract}

Keywords: Critical Thinking, Problem Based Learning Method, Science Learning

\section{PENDAHULUAN}

Pendidikan sangat penting dan berpengaruh pada kehidupan manusia, karena dengan pendidikan manusia dapat berdaya guna dan mandiri. Pendidikan merupakan sarana untuk menyiapkan generasi masa kini dan masa depan. Hal ini berarti bahwa proses pendidikan yang dilakukan pada saat ini bukan semata-mata untuk hari ini, melainkan untuk masa depan. Dengan demikian pendidikan harus mengantisipasi apa yang akan terjadi di masa depan, dengan membekali berbagai kompetensi yang akan diperlukan di masa depan.

Dalam Peraturan Menteri Pendidikan Nasional No 20 Tahun 2003 Tentang Sistem Pendidikan Nasional menyatakan bahwa :

"Pendidikan adalah usaha sadar dan terencana untuk mewujudkan suasana belajar dan 
proses pembelajaran agar peserta didik secara aktif mengembangkan potensi dirinya untuk memiliki kekuatan spiritual, keagamaan, pengendalian diri, kepribadian, kecerdasan, akhlak mulia, serta keterampilan yang dimiliki dirinya masyarakat, bangsa, dan negara".

Kurikulum 2013 pada jenjang SD saat ini yang dipelajari tidak di sajikan setiap mata pelajaran tetapi menggunakan tematik yaitu gabungan dari beberapa pelajaran. Saat ini Kurikulum 2013 sudah digunakan untuk kelas 1 sampai kelas 6. Pembelajaran di jenjang sekolah dasar (SD) pada saat ini masih jauh dari yang kita harapkan meskipun menggunakan kurikulum baru. Bagi peserta didik, fungsi kurikulum adalah sebagai sarana untuk mengukur kemampuan diri dan konsumsi pendidikan. Hal ini berkaitan juga dengan pengejaran target target yang membuat peserta didik dapat mudah memahami berbagai materi ataupun melaksanakan proses pembelajaran setiap harinya dengan mudah.

Berdasarkan hasil observasi awal di SD Negeri Pinang 6 Kecamatan Pinang Kota Tangerang khususnya dengan wali kelas IV yaitu Ibu Khodijah dalam proses pembelajaran masalah yang ditemukan pada saat pengamatan yaitu ketika guru mengajukan pertanyaan kepada siswa, hanya 8 siswa saja yang mengangkat tangan siap untuk menjawab pertanyaan yang diajukan dari 40 siswa, selain itu siswa juga tidak bertanya mengenai materi IPA yang diajarkan kepada guru selama kegiatan pembelajaran berlangsung. Artinya siswa pasif selama mengikuti pembelajaran dan hanya beberapa siswa yang merespon sedangkan siswa yang lain cuek.

Kemampuan berpikir kritis siswa khususnya dalam memberikan penjelasan yang rinci, logis, dan sitematis masih kurang. Hal ini terlihat dari jawaban siswa yang hanya jawaban singkat atau mengutip dari buku pegangan siswa yaitu buku Tema dan IPA. Siswa kurang didorong untuk mengembangkan kemampuan berpikirnya dan hanya siap merekam apa yang disampaikan guru di depan kelas, masalah lain yang muncul dikelas tersebut yaitu kegiatan belajar lebih ditandai dengan hafalan, dengan kata lain siswa hanya disuruh untuk menghafalkan isi materi pelajaran dari pada di ajak untuk berpikir kritis mengembangkan daya berpikir siswa.

Padahal sesuai perkembangan era modern sekarang ini, pendidikan semakin bergantung dengan tingkat kualitas yang dihasilkan. Untuk itu guru harus mampu menemukan solusi yang tepat dan bisa memanfaatkan sumber-sumber yang tersedia secara optimal agar dapat merangsang siswa untuk berpikir kritis dalam pembelajaran IPA. Disisi lain kegiatan belajar hanya menekankan pada penguasaan materi sebanyak -banyaknya sehingga siswa menganggap 
materi pembelajaran hanya untuk dihafalkan, tidak untuk dimengerti dan dikembangkan, sehingga dari pengamatan yang dilakukan beberapa siswa merasa bosan dan tidak tertarik mengikuti pelajaran. Siswa hanya sekedar mendengarkan penjelasan guru, sesekali mencatat hal-hal penting, tetapi jika ditanya kembali mengenai apa yang dijelaskan guru, mereka masih sulit menjelaskan kembali menurut bahasa sendiri.

Selain Faktor di atas, media dan juga alat peraga menjadi salah satu faktor yang menyebabkan rendahnya kemampuan berpikir kritis pada siswa kelas IV SDN Pinang 6. Berdasarkan uraian di atas, maka peneliti tertarik melakukan penelitian tindakan kelas dengan judul skripsi "Peningkatan Kemampuan Berpikir Kritis Melalui Metode Problem Based Learning (PBL) Pada Siswa Kelas IV SD Negeri Pinang 6 Kecamatan Pinang Kota Tangerang Tahun Pelajaran 2018/2019',

Sekolah artinya belajar menggunakan pikiran dengan baik, berpikir kritis menghadapi persoalan-persoalan penting serta menanamkan kebiasaan untuk berpikir. Berpikir krtis merupakan sebuah proses yang terarah dan jelas digunakan mengambil keputusan, membujuk, menganalisis asumsi, dan melakukan penelitian ilmiah. Hal ini membuat berpikir keberadannya menjadi penting dalam dunia pendidikan terutama dalam proses pembelajaran untuk siswa. Sebagai fasilitator dalam proses pembelajaran, guru memiliki kemampuan untuk ikut andil dalam mengembangkan kemampuan berpikir siswa, seorang pendidik dapat melatih siswanya dengan cara menunjukkan cara berpikir melalui semata-mata pelajaran. Memberikan contoh-contoh kasus cara berpikir yang baik memberikan masalah yang menuntut siswa berpikir, dan menerapkan keterampilan untuk mengambil keputusan.

Berpikir pada umumnya sebagai proses mental yang dapat menghasilkan pengetahuan. Berpikir berarti meletakkan hubungan antar bagian pengetahuan yang diperoleh manusia. Adapun yang dimaksud pengetahuan disini mencakup segala konsep, gagasan, dan pengertian yang telah dimiliki atau diperoleh manusia. Berpikir sebagai proses menentukan hubunganhubungan secara bermakna antara aspek-aspek dari suatu bagian pengetahuan (Sagala, 2013) Selanjutnya berpikir adalah daya jiwa yang dapat meletakkan hubungan -hubungan antara pengetahuan kita. Berpikir itu merupakan proses yang "dialektis" artinya selama kita berpikir, pikiran kita dalam keadaan tanya jawab, untuk dapat meletakkan hubungan pengetahuan kita. Dalam berpikir kita memerlukan alat yaitu akal (ratio). Hasil berpikir itu dapat diwujudkan dengan bahasa (Ahmadi \& Surpriyono, 2013). Kemampuan berpikir adalah syarat memahami sesuatu. Untuk mengetahui isi bacaan diperlukan kognisi siswa kemampuan berpikir yang dimaksud adalah kemampuan mengingat, memahami, menerapkan, menganalisis mesintesis 
tentang apa yang dibacanya. Di sini kemampuan berpikir yang kritis dapat mempermudah seorang pembaca memahami isi bacaannya (Dalman, 2017).

Menurut Tapilow (1997) berpikir kritis merupakan cara berpikir disiplin dan dikendalikan oleh kesadaran. Cara berpikir ini mengikuti alur logis dan rambu -rambu pemikiran yang sesuai dengan fakta atau teori yang diketahui. Tipe berpikir ini mencerminkan pikiran yang terarah (Susanto, 2014). Reber (1988) mengartikan berpikir kritis siswa dituntut menggunakan strategi kognitif tertentu yang tepat untuk men menguji keandalan gagasan pemecahan masalah dan mengatasi kesalahan atau kekurangan (Syah, 2014). Berpikir kritis adalah pertimbangan yang aktif, terus-menurus, dan teliti mengenai sebuah keyakinan atau bentuk pengetahuan yang diterima begitu saja dipandang dari sudut alasan - alasan yang mendukung dan kesimpulan - kesimpulan lanjutan yang menjadi kecendrungannya (Fisher, 2008).

Gagne (2010), science should be viewed as a way of thinking in the pursuit of understanding nature, as a way of investigating claims about phenomena, and as a body of knowledge that has resulted from inquiry, (IPA harus dipandang sebagai cara berfikir dalam pencarian tentang pengertian rahasia alam, sebagai cara penyelidikan terhadap gejala alam, dan sebagai batang tubuh pengetahuan yang dihasilkan dari inkuiri) (Wisudawati \& Slistyowati, 2014). Carin dan Sund (1993) mengidentifikasikan IPA sebagai "pengetahuan yang sistematis dan tersusun secara teratur, berlaku umum (universal), dan berupa kumpulan data hasil observasi dan eksperimen". IPA merupakan salah satu mata pelajaran pokok dalam kurikulum pendidikan di Indonesia terutama Kurikulum 2013, termasuk pada jenjang pendidikan sekolah dasar. Dengan demikian IPA adalah usaha manusia dalam memahami lingkungan alam semesta melalui pengamatan dengan menggunakan prosedur dan dijelaskan dengan penalaran seseorang, sehingga dapat membuat suatu kesimpulan yang tepat.

Pembelajaran berbasis masalah atau Problem Based Learning adalah sebuah metode pembelajaran yang berkaitan dengan siswa terhadap masalah-masalah yang dihadapi ketika pembelajaran berlangsung. Problem Based Learning pengajaran yang berhubungan dengan permasalahan nyata atau fakta bertujuan untuk memecahkan suatu masalah. Kegiatan proses penyelesaian masalah pembelajaran dengan secara sistematis. Pada metode Problem Based Learning memiliki kelebihan yaitu kelebihan metode Problem Based Learning yang sangat berpengaruh pada rasa semangat peserta didik dalam pembelajaran untuk memecahkan masalah dan membangun pengetahuannya sendiri melalui aktifitas belajar serta mengurangi beban siswa dengan mengahafal dan menyimpan informasi yang tidak perlu dipelajari.

Sesuai dengan namanya, pembelajaran berbasis masalah (PBM,Problem Based 
Learning) menurut (Kokasih \& Mulyadi, 2014) adalah model pembelajaran yang berdasar pada masalah-masalah yang dihadapi siswa terkait dengan KD yang sedang dipelajari siswa. Sekilas metode pembelajaran berbasis masalah menurut Jumanta (2014) dapat diartikan sebagai rangkaian aktivitas pembelajaran yang menekankan para proses penyelesaian masalah yang dihadapi secara ilmiah. Lebih jauh lagi Duch (1995) mendefinisikan Problem Based Learning (PBL) atau Pembelajaran Berbasis Masalah (PBM) adalah model pengajaran yang bercirikan adanya permasalahan nyata sebagai konteks untuk para peserta didik belaja $r$ berpikir kritis dan keterampilan memecahkan masalah serta memperoleh pengetahuan (Shoimin, 2016).

\section{METODE PENELITIAN}

Tempat penelitian di lakukan di kelas IV SD Negeri Pinang 6 yang berlokasi di Jl Matahari Kelurahan Sudimara Pinang Kecamatan Pinang Kota Tangerang .Waktu penelitian ini dilakukan di bulan Januari 2019 - April 2019. Pendekatan dalam penelitian ini adalah penelitian Tindakan Kelas (PTK), sedangkan jenis metode penelitian yang digunakan adalah “Metode Problem Based Learning”. Sampel penelitian ini adalah siswa kelas IVA SD Negeri Pinang 6 yang berjumlah 40 siswa. Teknik yang digunakan dalam pengambilan sampel adalah soal uraian .Teknik analisis data menggunakan metode Problem Based Learning. Dalam proses analisis ini menggunakan proses analisis data kuantitatif dan kualitatif. Dengan menggunakan observasi (pengamatan), soal test uraian, dokumentasi dan catatan lapangan.

\section{HASIL DAN PEMBAHASAN}

Jenis penelitian ini adalah Penelitian Tindakan Kelas (PTK). Penelitian Tindakan Kelas yang dilakukan oleh guru atau peneliti dengan tujuan untuk meningkatkan kualitas mengajarnya atau kualitas mengajar sejawatnya, atau untuk menguji asumsi-asumsi dalam teori-teori pendidikan dalam praktek atau kenyataan dikelas, atau juga untuk menimplementasikan, atau mengevaluasi, kebijakan -kebijakan sekolah. Dalam PTK ini peneliti menggunakan model Kemmis dan Taggart, model ini terdiri dari empat k egiatan pokok, yaitu perencanaan (planning), tindakan (acting), pengamatan (observing), dan refleksi (reflecting). 


\section{Gambar 1. Model Kemmis and Taggart}

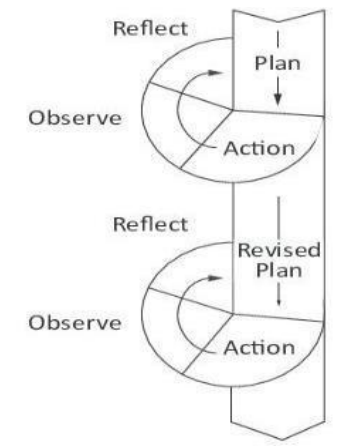

Siklus yang dipakai dalam model ini berlangsung beberapa kali sehingga tercapai tujuan yang dapat diinginkan. Desain penelitian tindakan kelas pada penelitian ini dirancang untuk dapat menyelesaikan suatu pokok bahasan yang akan dilaksanakan tindakan sesuai dengan perubahan yang ingin dicapai. Menurut (Suharsimi, Suhardjono, \& Supardi, 2015) Model Penelitian Tindakan Kelas (PTK) dapat dikatakan penelitian eksperimen berulang atau eksperimen berkelanjutan, meskipun tidak selalu demikian. Apabila guru tidak puas dengan hasil pembelajarannya, dan ia ingin mengubah pembelajaran itu dengan model yang sifatnya baru sehingga ia mencobanya. Mencobanya tidak hanya satu kali saja, tetapi berulang-ulang sehingga penelitiannya itu disebut penelitian tindakan .

Soal yang telah dibuat oleh peneliti, sebelumnya dilakukan uji cob a instrumen pada siswa kelas IV A SD Negeri Pinang 6 yang berjumlah 40 siswa. Kemudian, soal tersebut terdistribusi berdasarkan indikator dari variabel kemampuan berpikir kritis siswa. Setelah soal diuji cobakan, kemudian hasilnya di uji validitas dan reliabilitasnya, hasilnya dari 20 pernyataan soal yang valid terdapat 10, pernyataan soal tersebut layak digunakan dan telah memenuhi syarat validitas dan reliabiltas. Dalam tahap pengumpulan data peneliti menggunakan uji validitas butir pernyataan soal test, reliabilitas soal test sebelum instrumen soal ini kemudian diujikan pada sampel penelitian.

Tabel 1. Kemampuan Berpikir Kitis Siklus I

\begin{tabular}{ccccc}
\hline No & Niali (x) & Frekuensi & x.f & Persen \\
\hline $\mathbf{1}$ & 50 & 9 & 450 & $16,67 \%$ \\
\hline $\mathbf{2}$ & 60 & 8 & 480 & $17,78 \%$ \\
\hline $\mathbf{3}$ & 70 & 10 & 700 & $25,92 \%$ \\
\hline $\mathbf{4}$ & 80 & 10 & 800 & $29,63 \%$ \\
\hline $\mathbf{5}$ & 90 & 3 & 270 & $10 \%$ \\
\hline & Jumlah & 40 & 2.700 & $100 \%$ \\
\hline
\end{tabular}


Kemampuan berpikir kritis siswa, peneliti merasa dalam pembelajaran siklus I ini belum optimal. Hal ini perlu ditingkatkan kembali oleh peneliti untuk membuat kegiatan pembelajaran yang efektif, dan melibatkan siswa agar hasilnya pun akan lebih baik lagi. Hal ini belum sesuai dengan harapan dalam penelitian ini, maka observer dan peneliti memutuskan penelitian ini dilanjutkan pada siklus II.

Tabel 2. Kemampuan Berpikir Kitis Siklus II

\begin{tabular}{ccccc}
\hline No & Niali (x) & Frekuensi & x.f & Persen \\
\hline $\mathbf{1}$ & 60 & 2 & 120 & $3,26 \%$ \\
\hline $\mathbf{2}$ & 70 & 6 & 420 & $11.41 \%$ \\
\hline $\mathbf{3}$ & 80 & 4 & 360 & $9,78 \%$ \\
\hline $\mathbf{4}$ & 90 & 4 & 380 & $10,33 \%$ \\
\hline $\mathbf{5}$ & 100 & 24 & 2.400 & $65,22 \%$ \\
\hline & Jumlah & 40 & 3.680 & $100 \%$ \\
\hline
\end{tabular}

Pada tabel 2 di atas dapat dilihat bahwa nilai rata-rata kelas mencapai 92. Pada siklus II ini ketuntasan belajar siswa mencapai $95 \%$ dan hanya 5\% yang belum memenuhi KKM. Dengan demikian dapat dikatakan bahwa pada siklus II hampir semua siswa berhasil mencapai ketuntasan belajar dan peningkatan kemampuan berpikir kritis pada pokok bahasan tersebut. Hal ini di duga karena perbaikan tindakan dari siklus I ke siklus II pada materi yang diajarkan oleh guru

Tabel 3. Nilai Rata-Rata Dan Persentase Kemampuan Berpikir Kritis Kondisi Awal, Siklus I, Dan Siklus II

\begin{tabular}{cccc}
\hline Siklus & $\begin{array}{c}\text { Nilai Rata- } \\
\text { rata kelas }\end{array}$ & Persentase & Keterangan \\
\hline Kondisi Awal & 62,25 & $40 \%$ & Hasil belum tercapai \\
\hline Siklus I & 67,5 & $57,5 \%$ & Hasil belum maksimal \\
\hline Siklus II & 92 & $95 \%$ & Hasil hampir maksimal \\
\hline
\end{tabular}

Dari grafik perbandingan diatas dapat diketahui bahwa terdapat kenaikan yang baik pada setiap proses pembelajaran maupun hasil belajar. Pada kondisi awal nilai siswa berada di atas KKM masih sangat sedikit yaitu yaitu sekitar 40\%, di siklus I siswa yang memiliki nilai di atas KKM 
mengalami peningkatan sebesar $57,5 \%$, dan peningkatan terbesar terjadi pada siklus II sebesar $95 \%$.

Grafik 1. Aktivitas Siswa Pada Siklus I dan Siklus II

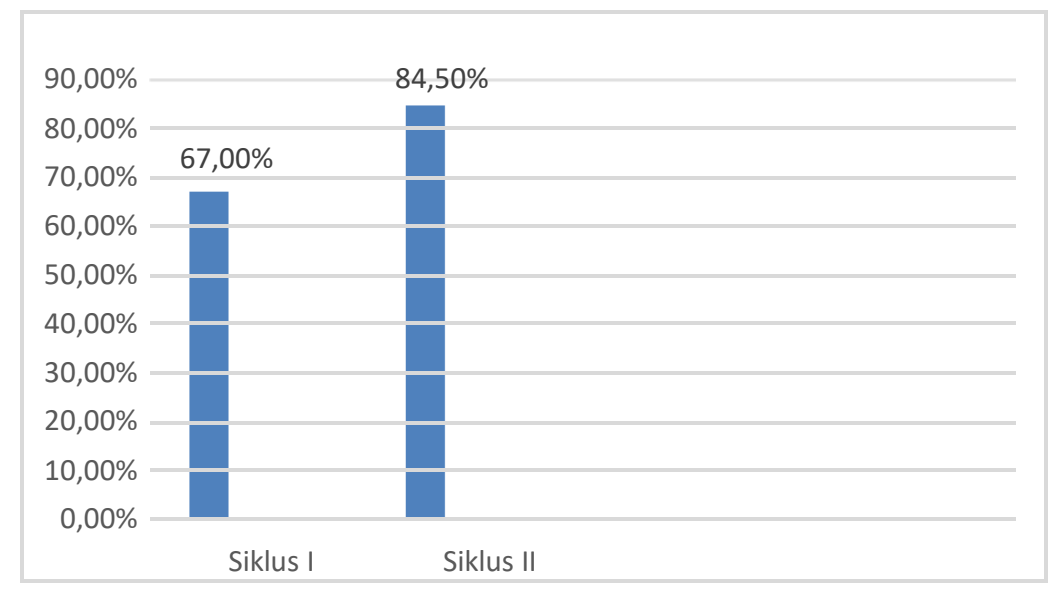

Grafik 2. Aktivitas Guru Pada Siklus I dan Siklus II

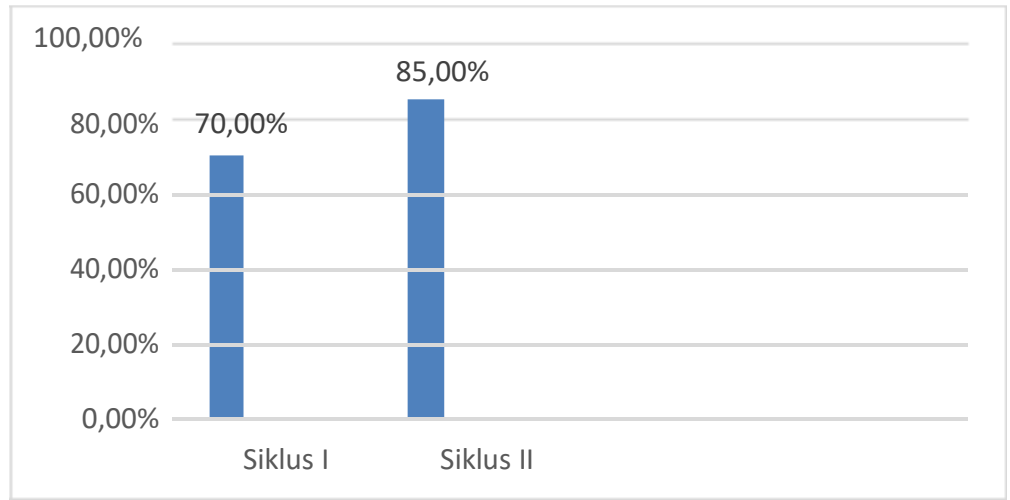

Pada garfik 1 untuk lembar observasi aktivitas siswa pada siklus I 67\%, sementara di siklus II mengalami peningkatan sebesar 84,50\%, dan pada grafik 2 lembar observasi aktivitas guru pun mengalami peningkatan setiap siklusnya, di siklus I lembar observasi memiliki perolehan ratarata $70 \%$, sementara di siklus II kenaikan yang diperoleh sudah sesuai dengan indikator yaitu 85\% dengan demikian dapat dikatakan kemampuan berpikir kritis siswa meningkat. Adapun peningkatan yang terjadi dikarenakan beberapa faktor antara lain, guru telah menggunakan metode pembelajaran yang sesuai sehingga siswa lebih mudah untuk memahami materi, dan dengan menggunakan metode yang tepat siswa menjadi lebih aktif dalam proses pembelajaran sehingga kemampuan berpikir kritis siswa meningkat dan proses pembelajaran menjadi lebih baik dan aktif.

Metode Problem Based Learning dapat meningkatkan kemampuan berpikir kritis IPA siswa kelas IV karena metode Problem Based Learning merupakan pembelajaran yang 
mengaharuskan siswa untuk berpikir kritis dan memecahkan masalahnya sendiri secara ilmiah dan sistematis yang telah disampaikan oleh guru ketika pembelajaran sedang berlangsung di dalam kelas, selain itu metode Problem Based Learning merupakan metode pembelajaran yang melibatkan siswa sepenuhnya kedalam proses pembelajaran karena disini guru hanya sabagai fasilitator saja. Agar kemampun berpikir kritis siswa terus meningkat sebaiknya siswa sering dilatih dalam memecahkan suatu permasalahan yang dapat membangkitkan kemampuan berpikir. Kepada guru dalam mengajar lebih baiknya siswa diajak untuk melihat fakta dengan lebih teliti dan memberikan kesempatan kepada siswa dalam berpendapat serta mengajak siswa untuk bisa mengambil kesimpulan yang tepat. Dalam pemilihan metode dan model pun harus sesuai dengan materi yang akan diajarkan. Yang tidak kalah penting adalah bagaimana guru bisa menciptakan suasana kelas dan dapat menguasai kelas sehingga pembelajaran kondusif dan menyenangkan.

\section{KESIMPULAN}

Berdasarkan analisis data dan pembahasan hasil penelitian melalui Penelitian Tindakan Kelas (PTK) pada proses pembelajaran IPA pada siswa kelas IV sebelum adanya pembelajaran dilakukan atau kondisi awal di peroleh nilai rata- rata 62,5 masih dalam kategori kurang karena siswa yang memperoleh nilai di bawah KKM masih sangat banyak, dan setelah adanya pembelajaran pada siklus I dengan menggunakan Metode Problem Based Learning nilai rata-rata hasil belajar siswa meningkat yaitu 67,5 sedangkan pada siklus II siswa memperoleh nilai ratarata 92 dalam kategori baik dan seluruh siswa mendapat nilai diatas KKM. Untuk presentase nilai siswa yang sudah mencapai KKM kondisi awal 40\% siklus I dengan jumlah siswa 16 siswa, di siklus II sebesar $95 \%$ dengan jumlah siswa 38 siswa.

Sedangkan untuk presentase kenaikan hasil lembar observasi aktivitas guru dan siswa pada siklus I lembar observasi aktivitas guru adalah 70\%, pada siklus II sebesar $85 \%$, Sementara lembar observasi aktivitas siswa pada siklus I adalah 67\%, dan pada siklus II $84,50 \%$. Berdasarkan hasil penelitian yang didapat, maka dapat diambil kesimpulan bahwa Metode Problem Based Learning mampu meningkatkan kemampuan berpikir kritis siswa dalam pembelajaran IPA, dan mampu meningkatkan kemampuan guru dalam melaksanakan pembelajaran dilihat dari keaktifan siswa seperti aspek memperhatikan, bertanya kepada guru, menjawab pertanyaan, berpendapat, kerjasama dalam kelompok, mengerjakan soal, belajar menggunakan sumber, dan hasil kelompok dari siklus I sampai II sebagian besar aspek mengalami peningkatan. 


\section{DAFTAR PUSTAKA}

Ahmadi, A., \& Supriyono, W. (2013). Psikologi Pendidikan. Jakarta: Rineka Cipta.

Dalman. (2017). Keterampilan Membaca. Jakarta: PT. Raya Grafindo.

Fisher, A. (2008). Berpikir Kritis. Jakarta: Erlangga.

Kokasih, E., \& Mulyadi, Y. (2014). Strategi Belajar Dan Pembelajaran. Bandung: Yrama Widya.

Sagala, S. (2013). Konsep dan Makna Pembelajaran. Bandung: Alfabeta.

Shoimin, A. (2016). 68 Model Pembelajaran Inovatif. Yogyakarta: Ar-Ruzz Media.

Suharsimi, A., Suhardjono, \& Supardi. (2015). Penelitian Tindakan Kelas. Jakarta: PT. Bumi Aksara.

Susanto, A. (2014). Teori Belajar \& Pembelajaran. Jakarta: Kencana.

Syah, M. (2014). Psikologi Pendidikan. Bandung: PT. Remaja Rosdakarya.

Wisudawati, A., \& Slistyowati, E. (2014). Metodologi Pembelajaran IPA. Jakarta: Bumi Aksara. 